\title{
Preventive treatment in migraine. Used drugs and related variables. Results of the European work and migraine survey
}

\author{
Ma. Teófila Vicente-Herrero ${ }^{1 *}$, Ma. Victoria Ramírez-Iñiguez de la Torre ${ }^{1}$, Elena Ruíz-de la Torre ${ }^{2}$, and \\ Luis Reinoso-Barbero ${ }^{3}$ \\ ${ }^{1}$ Occupational Medicine, Work Group for Guidelines and Protocols, Spanish Association of Specialists in Occupational Medicine, Madrid, Spain; \\ ${ }^{2}$ Chairmanship, European Migraine and Headache Alliance, Brussels, Belgium; ${ }^{3}$ Occupational Medicine, Chairmanship, Spanish Association of \\ Specialists in Occupational Medicine, Madrid, Spain
}

\begin{abstract}
Background: Migraine is a chronic debilitating and costly illness, the etiology of which is not yet fully known. Treatment is based on the control of acute attacks and the prophylactic management of chronic forms. Objective: The objective of this study is to find out the migraine preventive treatments which are used by patients in different countries in Europe, as well as observing the differences according to their social and demographic conditions. Methods: A cross-sectional observational study performed by means of an anonymous web-based survey of 3342 patients from Spain, Italy, France, Portugal, Ireland, United Kingdom, Germany, and other European Union (EU) countries. Study variables: Age, gender, country, type of town/ city, level of studies completed, and rural or urban area have been dismissed. The different uses of preventive treatments are defined as: $i$ always take preventive treatments, I take seasonal preventive treatments, I do not take preventive treatments, I do not know what a preventive treatment is. Results: The regular use of preventive treatments increases with age, their use is greater in patients over the age of 40 years $(p<0.0001)$, and they are most commonly used in Spain, Germany, United Kingdom, Italy, and in the rest of the countries in the EU $(p<0.0001)$. Out of all of the countries included in this survey, Spain has the highest use of seasonal preventive medication $(p<0.0001)$. The lowest use of preventive treatments is in patients under the age of 40 years $(p=0.002)$ and in female patients $(p=0.028)$. The highest percentages of patients who do not use preventive treatments $(p<0.0001)$ are from Spain, Germany, and the rest of the countries in the EU. Young patients under the age of 40 years $(p<0.0001)$, patients in Spain, Germany, and the rest of the countries in the EU that were not included in the initial design $(p<0.0001)$ have the greatest lack of knowledge with regard to preventive treatments. Conclusions: The use of preventive pharmacological therapies in migraine remains low despite the fact that these therapies are scientifically backed. It is important to further develop the training of physicians and reinforce patient information, assessing patient preferences to improve their adherence to treatment.
\end{abstract}

Key words: Migraine. Preventive treatment. Public health.

Correspondence:

*Ma. Teófila Vicente-Herrero

E-mail: vicenteherreromt @gmail.com
Available online: 18-05-2020

Rev Mex Neuroci. 2020;21(3):82-89

www.revmexneurociencia.com

1665-5044/ @ 2020. Academia Mexicana de Neurología A.C. Published by Permanyer. This is an open access article under the CC BY-NC-ND license (http://creativecommons.org/licenses/by-nc-nd/4.0/). 


\section{Tratamiento preventivo en migraña. Fármacos usados y variables relacionadas. Resultados de la encuesta europea sobre trabajo y migraña}

\section{Resumen}

Antecedentes: La migraña es un trastorno crónico incapacitante y costoso, cuya etiología aún no se conoce completamente; el tratamiento se basa en el control de los ataques agudos y el manejo profiláctico de las formas crónicas. Objetivo: El objetivo de este trabajo es descubrir el uso de tratamientos preventivos en pacientes con migraña de países europeos y las diferencias observadas según sus condiciones sociales y demográficas. Método: Estudio observacional transversal mediante encuesta web anónima a 3342 pacientes de España, Italia, Francia, Portugal, Irlanda, Reino Unido, Alemania y otros países de la Unión Europea (UE). Variables de estudio: edad, sexo, país, tipo de ubicación, nivel de estudios y área rural o urbana. Las opciones de uso de los tratamientos preventivos recopilados son: tratamientos preventivos siempre, tratamientos preventivos en temporadas, «no tomo tratamiento preventivo»y «no sé qué es un tratamiento preventivo». Resultados: El uso de tratamientos preventivos es superior en los mayores de 40 años $(p<0.0001)$, con la mayor utilización en España, Alemania, Reino Unido, Italia y el resto de los países de la UE no incluidos en el diseño inicial ( $p<0.0001)$. España es el país con mayor uso de preventivos en temporadas (estacional) $(p<0.0001)$. El uso más bajo de tratamientos preventivos ocurre en personas menores de 40 años $(p=0.002)$ y en mujeres $(p=0.028)$. España, Alemania y el resto de los países de la UE tienen el mayor porcentaje de pacientes sin tratamiento preventivo $(p<0.0001)$. La mayor falta de conocimiento sobre los preventivos ocurre en pacientes con menos de 40 años de edad ( $p<0.0001$ ), en España, Alemania y el resto de los países de la UE no incluidos en el diseño inicial ( $p<0.0001)$. Conclusiones: El uso de terapias farmacológicas preventivas en la migraña sigue siendo bajo a pesar de contar con respaldo científico. Es importante reforzar la capacitación del médico y la información al paciente, evaluando las preferencias del paciente para mejorar su adherencia al tratamiento.

Palabras clave: Migraña. Tratamiento preventivo. Salud pública.

\section{Introduction}

Migraine is a debilitating and costly chronic illness, the etiology of which is not yet fully known; however, it is understood that it is partly attributable to genetically determined factors that play a relevant role. It is estimated that migraines affect $18 \%$ of women and $6 \%$ of men ${ }^{1}$.

Treatment is based on the control of acute attacks and the prophylactic management of chronic forms. This includes the use of different categories of medication, although it has been demonstrated that not all subjects have the same clinical response to these forms of medication. The general picture is further exacerbated by the need for the frequent use of polytherapy to treat comorbidities, which may interfere with the pharmacologic action of migraine medications, including both symptomatic and preventative treatments. The main objective of personalized medicine is to set optimal therapies in the light of the functional biochemical active substance and of the comorbidities of each individual patient, to obtain the best clinical response. There are now novel therapeutic perspectives that have provided options for managing this pathology; nonetheless, the pharmacologic interactions and their metabolic destiny must always be studied by the application of pharmacogenomics ${ }^{2}$.
In the last decade, migraine research has identified novel pharmacologic targets and therapies that represent great progress ${ }^{3}$. However, preventive treatments continue to be underused, and this is due to significant factors, including adherence to treatment and patient preferences. Adherence to therapy, though a key factor for successful treatment, is low among patients with chronic conditions such as migraines. Dose frequency plays a major role in adherence, as is having flexible dosing options which allow for greater and better acceptance and adherence to treatment among adults with migraine ${ }^{4}$.

The objective of this study is to find out whether preventive treatments are used by patients with migraine in different countries in Europe, as well as observing the differences according to their social and demographic conditions, as by doing so it will be possible to contemplate more effective and targeted actions based on the results obtained.

\section{Methods}

A cross-sectional observational study performed by means of an anonymous web-based multiple-choice questionnaire with 32 questions, not validated, located on the European Migraine and Headache Alliance (EMHA)'s website, and scientifically backed by the Spanish Association of Specialists in Occupational 
Medicine (AEEMT). 3352 patients participated from Spain, Italy, France, Portugal, Ireland, United Kingdom, Germany, and other European Union (EU) countries which were not included in the initial study design and who responded to it. The inclusion criteria were that the patients must have been previously diagnosed with migraines, be working at the time of the questionnaire, or have been working in the previous year, and the patients had to participate voluntarily. The data were collected from September 2018 to January 2019.

Based on the initial description, the responses corresponding to the management of the migraines were analyzed according to sociodemographic variables: age up to 20 years, between 21 and 40 , between 41 and 60, more than 61; gender: man, and woman; place of residence: Spain, Italy, France, Portugal, Ireland, United Kingdom, Germany, and other country in the EU; type of town/city where they live: up to 500 inhabitants, 501-10,000 inhabitants, 10,001-250,000 inhabitants, 250,001-1 million inhabitants, and more than a million inhabitants; level of studies completed: elementary, intermediate, and higher; and environment in which they live: rural (town) and urban (capital).

The options for preventive treatment were defined by question 12 of the survey: i always take preventive treatment, I take seasonal preventive treatment, I always take several preventive treatments, I take several seasonal preventive treatments, I do not take preventive treatments, I do not know what a preventive treatment is.

Bivariate analysis was performed for each of the proposed options, as well as in relation to the different sociodemographic parameters.

Contingency tables were presented, which showed the absolute frequency $(n)$ and the percentage (\%) for each cross tab. Depending on the nature of the variables in the survey (categorical variables), the Chisquared test or Fisher's exact test was used to analyze the possible relationship between the characteristics of the migraine and the sociodemographic variables.

The data for each of the possible answers were analyzed separately.

\section{Results}

The sociodemographic characteristics of the population who responded to the survey are shown in table 1 and indicate a heterogeneous distribution by country, and the highest percentage of responses was received from Spain and Germany. About $85.13 \%$ of the individuals who filled out the survey were in the middle age block and were predominantly women $(90 \%)$. The
Table 1. Sociodemographic characteristics of the surveyed population

\begin{tabular}{|c|c|}
\hline Variable & n (\%) \\
\hline $\begin{array}{l}\text { Age (years) } \\
<20 \\
\text { Between } 21 \text { and } 40 \\
\text { Between } 41 \text { and } 20 \\
>61\end{array}$ & $\begin{array}{c}394(11.79) \\
1436(42.97) \\
1409(42.16) \\
103(3.08)\end{array}$ \\
\hline $\begin{array}{l}\text { Sex } \\
\text { Man } \\
\text { Woman }\end{array}$ & $\begin{array}{c}335(10.02) \\
3008(89.98)\end{array}$ \\
\hline $\begin{array}{l}\text { Level of studies completed } \\
\text { Elementary } \\
\text { Intermediate } \\
\text { Higher }\end{array}$ & $\begin{array}{c}134(4.01) \\
900(26.94) \\
2307(69.05)\end{array}$ \\
\hline $\begin{array}{l}\text { Supportive environment } \\
\text { Good } \\
\text { Regular } \\
\text { Bad }\end{array}$ & $\begin{array}{c}939(28.11) \\
1472(44.06) \\
930(27.84)\end{array}$ \\
\hline $\begin{array}{l}\text { Country of residence } \\
\text { Spain } \\
\text { Italy } \\
\text { France } \\
\text { Portugal } \\
\text { Ireland } \\
\text { United Kingdom } \\
\text { Germany } \\
\text { Other EU country }\end{array}$ & $\begin{array}{c}1039(31.13) \\
279(8.36) \\
87(2.61) \\
132(3.95) \\
222(6.65) \\
299(8.96) \\
704(21.09) \\
576(17.26)\end{array}$ \\
\hline $\begin{array}{l}\text { Size of town/city } \\
\text { Up to } 500 \text { inhabitants } \\
\text { From } 500 \text { to } 10,000 \text { inhabitants } \\
\text { From } 10,000 \text { to } 250,000 \text { inhabitants } \\
\text { From } 250,000 \text { to } 1 \text { million inhabitants } \\
\text { More than one million inhabitants }\end{array}$ & $\begin{array}{c}136(4.08) \\
782(23.43) \\
1251(37.49) \\
451(13.52) \\
717(21.49)\end{array}$ \\
\hline $\begin{array}{l}\text { Area of residence } \\
\text { Rural (town) } \\
\text { Urban (capital) }\end{array}$ & $\begin{array}{l}1048(31.37) \\
2293(68.63)\end{array}$ \\
\hline
\end{tabular}

EU: European Union.

majority of the participants responded that they lived in an urban environment $(68.63 \%)$, in medium-large sized cities (35\% in towns/cities with more than 250,000 inhabitants and $72.5 \%$ in towns/cities with more than 10,000 inhabitants), that they were qualified workers (69\% with higher studies and $27 \%$ with intermediate studies), and that they received moderate support from their environment during the migraine attacks (44.06\%).

The overall results for the use of the different preventive treatment options for migraines and their percentual relationship with the different sociodemographic variables that have been studied are shown in table 2.

By differentiating between each of the preventive options in relation with the studied variables and by only taking the statistically significant results into account, we see that. 
Table 2. Preventive treatment of migraine crises and related variables

\begin{tabular}{|c|c|c|c|c|c|c|}
\hline \multirow[t]{2}{*}{ Variable } & \multicolumn{6}{|c|}{ Preventive treatment of the crisis } \\
\hline & $\begin{array}{c}\text { One } \\
\text { preventive } \\
\text { treatment } \\
\text { always, } \mathbf{n}(\%)\end{array}$ & $\begin{array}{l}\text { One } \\
\text { seasonal } \\
\text { preventive } \\
\text { treatment, } \\
n(\%)\end{array}$ & $\begin{array}{l}\text { Several } \\
\text { preventive } \\
\text { treatments } \\
\text { always, } \mathbf{n}(\%)\end{array}$ & $\begin{array}{l}\text { Several } \\
\text { seasonal } \\
\text { preventive } \\
\text { treatments, } \\
n(\%)\end{array}$ & $\begin{array}{l}\text { I do not } \\
\text { take } \\
\text { treatment, } \\
\text { n (\%) }\end{array}$ & $\begin{array}{c}\text { I do not know } \\
\text { what preventive } \\
\text { treatment is, } \\
n(\%)\end{array}$ \\
\hline $\begin{array}{l}\text { Age (years old) } \\
<20 \\
\text { Between } 21 \text { and } 40 \\
\text { Between } 41 \text { and } 60 \\
>61 \\
\text { Total }\end{array}$ & $\begin{array}{c}53(5.58) \\
374(39.41) \\
496(52.27) \\
26(2.74) \\
949(100)\end{array}$ & $\begin{array}{c}72(13.33) \\
250(46.3) \\
201(37.22) \\
17(3.15) \\
540(100)\end{array}$ & $\begin{array}{c}17(5.4) \\
134(42.54) \\
156(49.52) \\
8(2.54) \\
315(100)\end{array}$ & $\begin{array}{c}13(7.26) \\
75(41.9) \\
86(48.04) \\
5(2.79) \\
179(100)\end{array}$ & $\begin{array}{c}175(13.77) \\
561(44.14) \\
491(38.63) \\
44(3.46) \\
1271(100)\end{array}$ & $\begin{array}{l}120(34.09) \\
152(43.18) \\
76(21.59) \\
4(1.14) \\
352(100)\end{array}$ \\
\hline $\begin{array}{l}\text { Gender } \\
\text { Man } \\
\text { Woman } \\
\text { Total }\end{array}$ & $\begin{array}{c}88(9.26) \\
862(90.74) \\
950(100)\end{array}$ & $\begin{array}{c}48(8.89 \\
492(91.11 \\
540(100)\end{array}$ & $\begin{array}{c}26(8.25) \\
289(91.75) \\
315(100)\end{array}$ & $\begin{array}{c}17(9.44) \\
163(90.56) \\
180(100)\end{array}$ & $\begin{array}{c}146(11.51) \\
1122(88.49) \\
1268(100)\end{array}$ & $\begin{array}{c}42(11.93) \\
310(88.07) \\
352(100)\end{array}$ \\
\hline $\begin{array}{l}\text { Country } \\
\text { Spain } \\
\text { Italy } \\
\text { France } \\
\text { Portugal } \\
\text { Ireland } \\
\text { United Kingdom } \\
\text { Germany } \\
\text { Other EU country } \\
\text { Total }\end{array}$ & $\begin{array}{c}178(18.76) \\
106(11.17) \\
31(3.27) \\
41(4.32) \\
70(7.38) \\
142(14.96) \\
175(18.44 \\
206(21.71) \\
949(100)\end{array}$ & $\begin{array}{c}184(34.07) \\
50(9.26) \\
8(1.48) \\
22(4.07) \\
38(7.04) \\
42(7.78) \\
128(23.7) \\
68(12.59) \\
540(100)\end{array}$ & $\begin{array}{c}76(24.05) \\
32(10.13) \\
7(2.22) \\
8(2.53) \\
35(11.08) \\
40(12.66) \\
61(19.3) \\
57(18.04) \\
316(100)\end{array}$ & $\begin{array}{c}49(27.53) \\
17(9.55) \\
4(2.25) \\
4(2.25) \\
10(5.62) \\
23(12.92) \\
40(22.47) \\
31(17.42) \\
178(100)\end{array}$ & $\begin{array}{c}483(38.09) \\
81(6.39) \\
34(2.68) \\
52(4.1) \\
66(5.21) \\
80(6.31) \\
252(19.87) \\
220(17.35) \\
1268(100)\end{array}$ & $\begin{array}{c}178(50.71) \\
5(1.42) \\
5(1.42) \\
9(2.56) \\
23(6.55) \\
7(1.99) \\
86(24.5) \\
38(10.83) \\
351(100)\end{array}$ \\
\hline $\begin{array}{l}\text { Characteristics of the town/city } \\
<500 \text { inhabitants } \\
500-1,000 \text { inhabitants } \\
>10,000-250,000 \text { inhabitants } \\
>250,000-1 \text { million inhabitants } \\
>1 \text { million inhabitants } \\
\text { Total }\end{array}$ & $\begin{array}{c}46(4.87) \\
227(24.05) \\
355(37.61) \\
124(13.14) \\
192(20.34) \\
944(100)\end{array}$ & $\begin{array}{c}24(4.44) \\
125(23.15) \\
191(35.37) \\
80(14.81) \\
120(22.22) \\
540(100)\end{array}$ & $\begin{array}{c}12(3.81) \\
73(23.17) \\
115(36.51) \\
32(10.16) \\
83(26.35) \\
315(100)\end{array}$ & $\begin{array}{c}13(7.26) \\
32(17.88) \\
68(37.99) \\
29(16.2) \\
37(20.67) \\
179(100)\end{array}$ & $\begin{array}{l}40(3.15) \\
286(22.5) \\
506(39.81) \\
172(13.53) \\
267(21.01) \\
1271(100)\end{array}$ & $\begin{array}{l}15(4.26) \\
91(25.85) \\
126(35.8) \\
49(13.92) \\
71(20.17) \\
352(100)\end{array}$ \\
\hline $\begin{array}{l}\text { Level of studies completed } \\
\text { Elementary } \\
\text { Intermediate } \\
\text { Higher } \\
\text { Total }\end{array}$ & $\begin{array}{c}34(3.58) \\
252(26.5) \\
665(69.93) \\
951(100)\end{array}$ & $\begin{array}{c}19(3.53) \\
155(28.76) \\
365(67.72) \\
539(100)\end{array}$ & $\begin{array}{c}9(2.86) \\
78(24.76) \\
228(72.38) \\
315(100)\end{array}$ & $\begin{array}{c}6(3.35) \\
47(26.26) \\
126(70.39) \\
179(100)\end{array}$ & $\begin{array}{c}52(4.09) \\
318(25.04) \\
900(70.87) \\
1270(100)\end{array}$ & $\begin{array}{c}26(7.41) \\
136(38.75) \\
189(53.85) \\
351(100)\end{array}$ \\
\hline $\begin{array}{l}\text { Environment in which they live } \\
\text { Rural (Town) } \\
\text { Urban (Capital) } \\
\text { Total }\end{array}$ & $\begin{array}{c}317(33.37) \\
633(66.63) \\
950(100)\end{array}$ & $\begin{array}{c}175(32.41) \\
365(67.59) \\
540(100)\end{array}$ & $\begin{array}{c}112(35.67) \\
202(64.33) \\
314(100)\end{array}$ & $\begin{array}{c}55(30.9) \\
123(69.1) \\
178(100)\end{array}$ & $\begin{array}{l}378(29.76) \\
892(70.24) \\
1270(100)\end{array}$ & $\begin{array}{c}109(30.97) \\
243(69.03) \\
352(100)\end{array}$ \\
\hline
\end{tabular}

EU: European Union.

The use of preventive treatments increases with age in all cases (Table 3), and these treatments are most commonly used in patients over the age of 40 years. Preventive treatments are most commonly used in Spain, Germany, the United Kingdom, Italy, and the rest of the EU countries $(p<0.0001)$. Out of all of the countries, Spain is the country with the highest use of seasonal preventive medication (Table 4$)(p<0.0001)$. The use of preventive treatments is lowest in patients under the age of 40 years $(p=0.002)$ and in female patients $(p=0.028)$. Spain, Germany, and the rest of the countries in the EU have the highest percentage of patients who do not take preventive treatments $(p<0.0001)$ (Table 5). Patients under the age of 40 years $(p<0.0001)$ in Spain, Germany, and the rest of the countries in the EU that were not included in the initial design but who responded to the survey $(p<0.0001)$ (Table 6$)$ have the greatest lack of knowledge regarding preventive treatment.

\section{Discussion}

To be able to evaluate the rates and predictive factors of adequate care for patients with migraines, three 
Table 3. Preventive treatment of migraine crises and statistically significant variables*

\begin{tabular}{|l|c|c|c|}
\hline \multirow{2}{*}{ Variable } & \multicolumn{3}{|c|}{$\begin{array}{r}\text { Preventive treatment: preventive } \\
\text { treatment always }\end{array}$} \\
\cline { 2 - 3 } & No, n (\%) & Yes, n (\%) & p \\
\hline $\begin{array}{l}\text { Age (years old) } \\
<20\end{array}$ & $341(14.25)$ & $53(5.58)$ & $<0.0001$ \\
Between 21 and 40 & $1062(44.38)$ & $374(39.41)$ & \\
Between 41 and 60 & $913(38.15)$ & $496(52.27)$ & \\
$>61$ & $77(3.22)$ & $26(52.27)$ & \\
Total & $2393(100)$ & $949(100)$ & \\
\hline Country & & & \\
Spain & & & \\
Italy & $861(36.04)$ & $178(18.76)$ & $<0.0001$ \\
France & $173(7.24)$ & $106(11.17)$ & \\
Portugal & $56(2.34)$ & $31(3.27)$ & \\
Ireland & $91(3.81)$ & $41(4.32)$ & \\
United Kingdom & $152(6.36)$ & $70(7.38)$ & \\
Germany & $157(6.57)$ & $142(14.96)$ & \\
Other countries in the & $529(22.14)$ & $175(18.44)$ \\
EU & $370(15.49)$ & $206(21.71)$ \\
\hline Total & & & \\
\hline
\end{tabular}

*Only variables with $p<0.05$ are included. Gender, level of education, characteristics of the town/city, and area of residence have been dismissed as $p>0.05$.

EU: European Union.

essential steps are required: medical consultation, accurate diagnosis, and the minimal necessary pharmacologic treatment (with acute and preventive treatments). Socioeconomic, demographic, and headache-specific variables have a joint influence.

The Chronic Migraine Epidemiology and Outcomes study showed that more than $5 \%$ of people with chronic migraines have to traverse these barriers (consultation, diagnosis, and treatment), which represents an unmet need for improving care in this population group. The predictive factors in this professional consultation and in the adequate diagnosis and treatment indicate that the consultation increases with age, more in women, and likewise the need for public health efforts to improve the results obtained in patients with migraine through interventions and educational efforts aimed at improving the consultation rates, diagnostic accuracy, and adherence to minimal symptomatic and/or preventive pharmacologic treatment were indicated ${ }^{5}$.

The results from our survey demonstrated that age does not significantly modify the use of preventive treatments in migraine; nonetheless, statistically significant results were observed in terms of the lack of knowledge about or the non-use of these treatments; likewise, it was observed that younger patients know less about these preventive treatments (especially those patients aged under 20 years) and that it is
Table 4. Preventive treatment in the season of migraine crises and statistically significant variables*

\begin{tabular}{|l|c|c|c|}
\hline \multirow{2}{*}{ Variable country } & \multicolumn{3}{|c|}{$\begin{array}{c}\text { Preventive treatment: seasonal } \\
\text { preventive treatment }\end{array}$} \\
\cline { 2 - 3 } & No, n (\%) & Yes, n (\%) & p \\
\hline Spain & $855(30.56)$ & $184(34.07)$ & 0.018 \\
\hline Italy & $229(8.18)$ & $50(9.26)$ & \\
\hline France & $79(2.82)$ & $8(1.48)$ \\
\hline Portugal & $110(3.93)$ & $22(4.07)$ \\
\hline Ireland & $184(6.58)$ & $38(7.04)$ \\
\hline United Kingdom & $257(9.19)$ & $42(7.78)$ \\
\hline Germany & $576(20.59)$ & $128(23.7)$ \\
\hline Other EU country & $508(18.16)$ & $68(12.59)$ \\
\hline Total & $2798(100)$ & $540(100)$ \\
\hline
\end{tabular}

*Only variables with $p<0.05$ are included. Age, gender, level of studies completed, characteristics of the town/city, and area of residence have been dismissed as $\mathrm{p}>0.05$.

EU: European Union.

patients of adult age (between 41 and 60 years) who make the greatest use of said treatments.

Studies show that primary headaches, especially migraines, and tension-type headaches are some of the most frequent conditions at a young age. In the case of these young patients, even before pharmacological treatment, an appropriate lifestyle must be adopted, avoiding triggers, given that the specific and effective pharmacologic treatments for migraines and tension-type headaches are never lacking in side effects, nonetheless, in specific cases their recommended use is scientifically backed, both for specific medications for treating the crisis and the prophylactic pharmacologic therapies when the situation so requires ${ }^{6}$.

Most headaches in young patients can be classified according to the International Classification of Headache Disorders criteria. Migraine is the most frequent diagnosis, and it is commonly associated with a negative impact on the quality of life; however, the majority of young patients receive little preventive treatment before being referred to specialized clinics ${ }^{7}$.

The approach to headaches in young patients is complex; nonetheless, it is one of the most common conditions affecting children, adolescents, and young people in industrialized countries. Although effective pharmacologic treatments without secondary effects are still lacking, over the last few years, several options (Ginkgolide B) have proven to be an effective and well-tolerated preventive treatment for reducing 
Table 5. Preventive treatment of migraine crises and statistically significant variables*

\begin{tabular}{|l|c|c|c|}
\hline \multirow{2}{*}{ Variable } & \multicolumn{3}{|c|}{$\begin{array}{r}\text { Preventive treatment: without } \\
\text { preventive treatment }\end{array}$} \\
\cline { 2 - 3 } & No, n (\%) & Yes, n (\%) & p \\
\hline Age (years old) & $219(10.57)$ & $175(13.77)$ & 0.002 \\
$<20$ & $875(42.25)$ & $561(44.14)$ & \\
Between 21 and 40 & $918(44.33)$ & $491(38.63)$ & \\
Between 41 and 60 & $59(2.85)$ & $44(3.46)$ & \\
$>61$ & $2071(100)$ & $1271(100)$ & \\
Total & & & \\
\hline Gender & $189(9.11)$ & $146(11.51)$ & 0.028 \\
Man & $1886(90.89)$ & $1122(88.49)$ & \\
Woman & $2075(100)$ & $1268(100)$ & \\
Total & & & \\
\hline Country & & & \\
Spain & $556(26.86)$ & $483(38.09)$ & $<0.0001$ \\
Italy & $198(9.57)$ & $81(6.39)$ & \\
France & $53(2.56)$ & $34(2.68)$ & \\
Portugal & $80(3.86)$ & $52(4.1)$ & \\
Ireland & $156(7.54)$ & $66(5.21)$ & \\
United Kingdom & $219(10.58)$ & $80(6.31)$ & \\
Germany & $452(21.84)$ & $252(19.87)$ \\
Other EU country & $356(17.2)$ & $220(17.35)$ \\
\hline Total & $2070(100)$ & $1268(100)$ & \\
\hline & & & \\
\hline
\end{tabular}

*Only variables with $p<0.05$ are included. Level of studies completed characteristics of the town/city and area of residence have been dismissed as $\mathrm{p}>0.05$.

EU: European Union.

migraine attack frequency and in attenuating the use of symptomatic medication for primary headaches in this group of young patients ${ }^{8}$.

In our survey, no significant results were observed among men and women in the use of preventive therapy, although there seems to be a greater lack of awareness among men. In contrast, the Migraine in America Symptoms and Treatment study carried out in 2016 in the United States evaluated gender differences in sociodemographics and headache features, consultation and diagnosis patterns, and patterns of acute and preventive treatment for migraine. The results showed that men (14.5\%) were more likely than women $(10.4 \%)$ to take daily oral preventive medication ( $p<0.001$ ), but that in both, acute prescription and preventive migraine treatments are underused ${ }^{9}$.

In our survey, significant differences in the use of preventive treatments were observed depending on the country. Patients in Spain and Germany demonstrated the greatest lack of knowledge with regard to preventive treatment, and these treatments are least commonly used in Spain and Portugal. Italy, the United Kingdom, and other countries in the EU which were not included in the initial design but who responded to the questionnaire make the greatest use of one or several
Table 6. Preventive treatment of migraine crises and statistically significant variables*

\begin{tabular}{|c|c|c|c|}
\hline \multirow[t]{2}{*}{ Variable } & \multicolumn{3}{|c|}{$\begin{array}{c}\text { Preventive studies: } \mathrm{i} \text { do not know what } \\
\text { preventive treatment is }\end{array}$} \\
\hline & No & Yes & $\mathbf{p}$ \\
\hline $\begin{array}{l}\text { Age (years old) } \\
<20 \\
\text { Between } 21 \text { and } 40 \\
\text { Between } 41 \text { and } 60 \\
>61 \\
\text { Total } \\
\text { Not available }\end{array}$ & $\begin{array}{c}274(9.16) \\
1284(42.94) \\
1333(44.58) \\
99(3.31) \\
2990(100) \\
8\end{array}$ & $\begin{array}{c}120(34.09) \\
152(43.18) \\
76(21.59) \\
4(1.14) \\
352(100) \\
0\end{array}$ & $<0.0001$ \\
\hline $\begin{array}{l}\text { Country } \\
\text { Spain } \\
\text { Italy } \\
\text { France } \\
\text { Portugal } \\
\text { Ireland } \\
\text { United Kingdom } \\
\text { Germany } \\
\text { Other EU country } \\
\text { Total }\end{array}$ & $\begin{array}{c}861(28.82) \\
274(9.17) \\
82(2.75) \\
123(4.12) \\
199(6.66) \\
292(9.78) \\
618(20.69) \\
538(18.01) \\
2987(100)\end{array}$ & $\begin{array}{c}178(50.71) \\
5(1.42) \\
5(1.42) \\
9(2.56) \\
23(6.55) \\
7(1.99) \\
86(24.5) \\
38(10.83) \\
351(100)\end{array}$ & $<0.0001$ \\
\hline $\begin{array}{l}\text { Level of studies } \\
\text { completed } \\
\text { Elementary } \\
\text { Intermediate } \\
\text { Higher } \\
\text { Total }\end{array}$ & $\begin{array}{c}108(3.61) \\
764(25.55) \\
2118(70.84) \\
2990(100)\end{array}$ & $\begin{array}{c}26(7.41) \\
136(38.75) \\
189(53.85) \\
351(100)\end{array}$ & $<0.0001$ \\
\hline
\end{tabular}

*Only variables with $p<0.05$ are included. Gender, characteristics of the town/city, and area of residence have been dismissed as the $p>0.05$. EU: European Union.

preventive treatments always. There was no relationship between the size of town/city in terms of the number of inhabitants and the use of preventive treatments. Studies carried out in Spain among neurologists are in line with the majority of the internationally established guidelines where first choice preventive drugs are concerned. This is recorded in the survey which was recently carried out by the Spanish Society of Neurology ${ }^{10}$; however, the My Migraine Voice survey published in 2018 demonstrated that in a large proportion of patients with more than four migraine attacks per month, and for whom at least one preventive migraine treatment had failed which had led to resistance to use, future treatments could address existing unmet needs, allowing these individuals with migraine to be able to maximize their contribution to society ${ }^{11}$.

There are no statistically significant differences in our survey between the cultural level and the use of preventive treatments; however, there are differences in the knowledge of the same, as it is lower in patients with elementary or intermediate levels of studies than in those with higher levels of studies. 
With regard to the environment in which they live, our results do not show any relationship between this and the use or knowledge of these preventive treatments; however, prior systematic reviews of the global prevalence of migraine at the community level (302 studies which included 6,216,995 participants) showed that migraine affects one in ten people worldwide, with higher prevalence among women, among young people, and among urban residents in comparison with those living in a rural environments $(11.2 \%$ among urban residents and $8.4 \%$ among rural residents) ${ }^{12}$.

The results of our survey confirm the scarce use and knowledge of preventive treatments in migraine as confirmed by prior studies despite the scientific evidence that supports their use adjusted to international criteria. The American Academy of Neurology and the Canadian Headache Society have published evidence-based guidelines for preventive pharmacologic treatments for migraines that provide valuable guidance for clinicians; however, these pharmacologic therapies continue to be underused in clinical practice. The primary objective of these guidelines is to assist the practitioner in choosing an appropriate prophylactic medication for a person with migraine, based on current evidence in the medical literature and expert consensus. These guidelines are focused on patients with episodic migraine (headache on $\leq 14$ days a month) and there is good evidence from randomized controlled trials for the use of a number of different prophylactic medications in patients with migraines.

Medication choice for an individual patient requires careful consideration of patient clinical features ${ }^{13}$.

The principles of preventive treatment are important to improve compliance, minimize side effects, and improve patient outcomes. The choice of treatment should be based on the presence of comorbid and coexistent illness, patient preference, reproductive potential, and best available evidence ${ }^{14}$. The route of administration and preventive treatment-related adverse events has an impact on patient preference and their adherence to treatment ${ }^{15,16}$. Current treatment options for migraine prophylaxis are associated with poor tolerability and low adhesion and persistence, with an irregular course, frequent gaps, and discontinued prophylaxis by the end of the $1^{\text {st }}$ year ${ }^{17}$. Persistence to oral preventive treatments is poor at 6 months and declines further by 12 months. Switching between treatments is common, but persistence worsens as patients cycle through various preventive treatments ${ }^{18}$.

Scientific evidence supports the fact that preventive treatment is an important part of migraine therapy.
When prescribing medications, physicians should understand patient's preferences and select drugs that most closely meet their needs. Understanding the factors that influence these preferences increases physicians' ability to select appropriate migraine therapy. The results of patient surveys indicate that patients rated efficacy as the most important aspect of preventive therapy of migraine ${ }^{19}$. In addition to the functional impact of migraine, the decision to start prophylaxis is based on a complex of considerations from the patient's perspective (e.g., perceived burden of migraine, expected benefits or disadvantages, interaction with relatives, colleagues, and physician), therefore, when advising migraine patients about prophylaxis, their opinions should be taken into account. Patients need to be open to advice and information and intervention have to be offered at an appropriate moment in the course of migraine ${ }^{20}$.

The biases of this study include the use of a non-validated survey, the subjectivity of the responses, the greater participation by women, the non-uniform distribution of participants by countries, with greater participation from Spain and Germany, and the inclusion of respondent patients from countries that were not contemplated in the initial design.

The sample size and the comparative study by European countries are considered the strengths of this study, as well as the social and demographic variables that have been incorporated.

\section{Conclusions}

The use of preventive treatments increases with age, and the use of these treatments is greater in patients over the age of 40 years. The greatest lack of knowledge was observed among patients under the age of 40 years.

No relationship has been observed between the use of preventive treatments in migraine and the size of their place of residence or whether they live in a rural or urban area.

Knowledge of preventive treatments is lower in individuals with elementary or intermediate studies than in those with higher studies.

The greatest use of regular preventive treatments is in Spain, Germany, the United Kingdom, and Italy.

Spain and Germany have the greatest percentage of patients who do not take treatment or who do not know about preventive treatments. 
The use of preventive pharmacologic therapies in migraine remains low despite the fact that it is scientifically backed.

It is important to further develop the training of physicians and reinforce patient information, assessing patient preferences to improve their adherence to treatment.

\section{Acknowledgments}

We are grateful to the European Migraine and Headache Alliance (EMHA) patients for their voluntary collaboration in this survey, to the Spanish Association of Specialists in Occupational Medicine for its scientific support and backing, and to Silvia Lladosa for the statistical study of the data.

\section{Funding}

This work has been funded by the EMHA.

\section{Conflicts of interest}

There are no conflicts of interest in this work.

\section{Ethical disclosures}

Protection of human and animal subjects. The authors declare that the procedures followed were in accordance with the regulations of the relevant clinical research ethics committee and with those of the Code of Ethics of the World Medical Association (Declaration of Helsinki).

Confidentiality of data. The authors declare that no patient data appear in this article.

Right to privacy and informed consent. The authors declare that no patient data appear in this article.

\section{References}

1. Harmon TP. Diagnosis and management of migraines and migraine variants. Prim Care. 2015;42:233-41.

2. Pomes LM, Guglielmetti M, Bertamino E, Simmaco M, Borro M, Martelletti P. Optimising migraine treatment: from drug-drug interactions to personalized medicine. J Headache Pain. 2019;20:56.

3. Do TP, Guo S, Ashina M. Therapeutic novelties in migraine: new drugs, new hope? J Headache Pain. 2019;20:37.

4. Cowan R, Cohen JM, Rosenman E, lyer R. Physician and patient preferences for dosing options in migraine prevention. J Headache Pain. 2019;20:50.

5. Dodick DW, Loder EW, Manack Adams A, Buse DC, Fanning KM, Reed ML, et al. Assessing barriers to chronic migraine consultation, diagnosis, and treatment: results from the chronic migraine epidemiology and outcomes (CaMEO) study. Headache. 2016;56:821-34.

6. Usai S, Grazzi L, Bussone G. Gingkolide B as migraine preventive treatment in young age: results at 1-year follow-up. Neurol Sci. 2011;32 Suppl 1:S197-9.

7. Pedraza Hueso MI, Ruíz Piñero M, Martínez Velasco E, Juanatey García A, Guerrero Peral AL. Headache in young patients: clinical characteristics of a series of 651 cases. Neurologia. 2019;34:22-6.

8. Usai S, Grazzi L, Andrasik F, Bussone G. An innovative approach for migraine prevention in young age: a preliminary study. Neurol Sci. 2010;31 Suppl 1:S181-3.

9. Lipton RB, Munjal S, Alam A, Buse DC, Fanning KM, Reed ML, et al. Migraine in America symptoms and treatment (MAST) study: baseline study methods, treatment patterns, and gender differences. Headache. 2018:58:1408-26.

10. García-Azorin D, Santos-Lasaosa S, Gago-Veiga AB, Romero JV, Guerrero-Peral AL. Real world preventative drug management of migraine among Spanish neurologists. J Headache Pain. 2019;20:19.

11. Martelletti P, Schwedt TJ, Lanteri-Minet M, Quintana R, Carboni V, Diener $\mathrm{HC}$, et al. My migraine voice survey: a global study of disease burden among individuals with migraine for whom preventive treatments have failed. J Headache Pain. 2018;19:115.

12. Woldeamanuel YW, Cowan RP. Migraine affects 1 in 10 people worldwide featuring recent rise: a systematic review and meta-analysis of community-based studies involving 6 million participants. J Neurol Sci. 2017;372:307-15.

13. Pringsheim T, Davenport W, Mackie G, Worthington I, Aubé M, Christie SN, et al. Canadian headache society guideline for migraine prophylaxis. Can J Neurol Sci. 2012:39:S1-59.

14. Silberstein SD. Preventive migraine treatment. Continuum (Minneap Minn). 2015;21:973-89

15. Matza LS, Deger KA, Vo P, Maniyar F, Goadsby PJ. Health state utilities associated with attributes of migraine preventive treatments based on patient and general population preferences. Qual Life Res. 2019;28:2359-72.

16. Seng EK, Rains JA, Nicholson RA, Lipton RB. Improving medication adherence in migraine treatment. Curr Pain Headache Rep. 2015:19:24.

17. Woolley JM, Bonafede MM, Maiese BA, Lenz RA. Migraine prophylaxis and acute treatment patterns among commercially insured patients in the United States. Headache. 2017:57:1399-408.

18. Hepp Z, Dodick DW, Varon SF, Chia J, Matthew N, Gillard P, et al Persistence and switching patterns of oral migraine prophylactic medications among patients with chronic migraine: a retrospective claims analysis. Cephalalgia. 2017:37:470-85.

19. Peres MF, Silberstein S, Moreira F, Corchs F, Vieira DS, Abraham N, et al. Patients' preference for migraine preventive therapy. Headache. 2007:47:540-5.

20. Dekker F, Knuistingh Neven A, Andriesse B, Kernick D, Reis R, Ferrari MD, et al. Prophylactic treatment of migraine; the patient's view, a qualitative study. BMC Fam Pract. 2012;13:13 